\title{
Arabic Education and Modern Learning Construction in Muslim Minority Islamic Boarding School in Indonesia
}

\author{
Ismail Suardi Wekke \\ STAIN Sorong, Indonesia \\ Corresponding E-mail: iswekke@gmail.com
}

\begin{abstract}
Islamic boarding schools not only can bring up the religious enthusiasm, but also interpret Indonesia with a spirit of nationalism. Hence, it is not surprising that pesantren (Islamic Boarding School) is present to give a dedication to this nation aside from Islamic interest. Not only in the role of education,an educational institution like pesantren also had socio-cultural functions and role, a significant spiritual movement needs to be done to provide reinforcement towards empowerment within the goal of education holistically. A means that supports the learning process is the mastery of Arabic. This paper will describe the practice of Arabic teaching and learning in Muslim minority area with an approach to the principle of moderation. The research was carried out in West Papua which included five districts and one city. The results of the study showed that the application of learning that was carried out in Islamic boarding schools in Mayamuk, Aimas, Waisai, Teminabuan, Kaimana, Waigom, and Misol, was done in a well-structured. In the seven locations, Islamic education within the framework of the learning process that is based on language skills is carried out with the santri (Students) communicative approach.

The skill of the students that is trained is linguistic expression without special emphasis on grammar mastery. The environment of boarding schools that provide dormitories as a place to live becomes a tool of interaction among santri (students) in practicing language skills. The language ability of the students is adapted to the learning context along with the environment. The existing social aspects are used to support the learning process. Finally, this research concludes that differences in learning objectives and determining approach and methodological aspects will affect learning Arabic.
\end{abstract}

Keywords: Modern, Learning, Islamic Boarding School

\section{Introduction}

Since Arabic has become the language of the Al-Quran and Hadith, the movement or the eagerness to understand Arabic began as part of the tradition of understanding Islam. The meaning of Al-Quran is adorned by how far it can be understood by using the approach to Arabic. This can be done, if an individual is able to formulate the meaning of it with linguistic awareness in the beginning. But, whenever the education takes place, it always just emphasizes 
the aspect of Arabic as knowledge. And it does not make Arabic become a means in understanding Islam. If this is considered as a "failure", then the learning innovation called the Modern Islamic Boarding School make an effort to turn Arabic as a skill of language. Thus, it is no merely a reading matter that emphasizing the grammar and ability of qawaid, but rather the use of Qawaid and all its rules which can be an active language skill.

Islamic boarding schools in Indonesia are not only being a religious institution, but its role is more than it. In the beginning of the establishment of Islamic boarding schools, they are intended as an institution to accomplish religious understanding. The instillation of religious values is transformed within institutions which today are called pesantren (Dhofier 1982: 13). Islamic boarding schools have been developed as a typical Indonesian institution. Although it was referred to as an institution that adopted to the traditions of India and the Middle East, but in this context, Islamic boarding schools became a distinctive Indonesian institution. Not only for the religion concerns, Pesantren also has a role in the economic movement (Risti Permani : 2011). Prosperity and the involvement of the society in economic affairs turn to the impact of the implementation of education around them. At the same time the presence of pesantren has a financial impact, including capital turnover, and supports the distribution of goods and capital. In a study conducted by Mylek and Nel (2010: 81) religion can be functional to decrease the poverty. Thus, in this condition the spirit of religion becomes the basis of the economic movement.

Comparing to the previous case, the success of Arabic learning already gave rise to initiatives in the development of modern boarding schools. It starts from the concerns of Arabic learning which emphasizes the ability to understand language in terms of grammar but fail to use the grammatical rules in language expression. The existence of modern Islamic boarding schools led by Darussalam Modern Islamic Boarding School in Gontor, East Java, Ponorogo became the locomotive for the development of Islamic education (Basyir 1999). In addition to the choices to maintain the existing practices, The modern language learning model is a practice that is implemented by Gontor, then it developed to East Indonesia and other alumni boarding schools. Including in Makassar (Wekke, 2012), the IMMIM Islamic Boarding School is being the one of the institutions that uses this modern approach in Arabic teaching and learning.

The dissemination of religious education is not a practice that has just been implemented by Islamic boarding schools. But, the language learning method can cover the educational objectives set by the institution. This construction is much influenced by the educational ideology which understood by the pesantren caregivers, the Kyai (clerics) and the ustadz council (the teacher). The tradition that developed has always been related to locality and religious enthusiasm as acceptance of local conditions. An environment becomes a fertile land for the growth of a tradition. With the support of various parties who become elements in the management of the institution, including a culture that supports the continuity of an environment (Moos 1979). In this context, research on the implementation of modern methods in language education in Islamic boarding schools needs to be accomplished. This paper seeks to reveal the practice of modern Arabic language learning in Islamic education institutions in Muslim minority communities.

\section{Theoretical Support}

\section{A. Arabic Language, Tradition, and Diversity}


Arabic which becomes a communication tool in Islamic religious activities, eventually can be seen as not a foreign language. Thereby, this viewpoint leads to making the main focus in early learning, even before formal education in elementary school, a child has been directed to learn Al-Quran. It related to Arabic learning outright. When they were a child and introduced to this occurrence, in Gellel's (2007) view, it was interpreted as linguistic awareness that is led to virtue. Such as the characteristics of Arabic, Al-Quran has become a distinctive entity of its own. The Prophet's interlocutor was not the main reason when AlQuran was revealed and used Arabic for using Arabic as the language of Al-Quran. The Qur'an's literary value, although not a literary book, has such a distinctive feature. Dictions, sentence arrangements, expressions, and meanings that are being tools in conveying messages are intellectual and scientific discourses.

Especially in Meccan community, When the tribes encountered and made Mecca as a place for trade transaction, this is also supported by the existence of the Ka'bah as the marking building of the city and as a sanctified place. The language variations that made Arabic in Mecca had its speakers and a culture that encompassed them. Habits that are spoken, including the wording of speakers based on free choice, but it produces the elements that are understood by the native speakers. Since the beginning, Arabic has become the conveyor of ethnic values and identity. The complexity of Arabic oral language at that time showed each tribe has a distinctive linguistic dialect. Before the advent of Islam, poetry was known as an excellent works. The spoken words, the emergence of rivalry, and even the Ukaz market specifically visited by poets in uproar. The best poetry is then hung (mu'allaqat) in Ka'bah to become a monumental work. The honor, expression and musical value are all symbolized by the beauty of poetry and qasidah. At this point, Arabic had a very important position for the encountering of each tribe in Mecca. The presence of Ka'bah made Mecca's strategic position as the most important of Arab sanctuary. The award for the best poet was also given in Ka'bah.

The relation between Arabic and Islam is intertwined of Arabic as the main language for delivering Islamic teachings. Some Islamic traditions grew from Arabic culture. Although it cannot be interpreted that Arab is Islam. Including with the dissemination of Islam into teachings that are accepted in all corners of the world. Arab culture just occupies a certain place. Meanwhile, Islam went through beyond national borders and identities. The development of Islam in a particular region brought Arabic as one of the media. Unfortunately, the poetry that has become part of Arab literature is not growing in tandem. From this case, Islam and Arabic are interpreted as two inseparable things. Religion became a symbol that is not limited by the ethnicity and limited identity. Precisely, religion then institutionalizes in identity, social relations, and also interpretation (Woodhead 2011: 121).

There is a concern from Arabs for standardization by establishing the grammatical, as a symbol of culture and literature. Sometimes, the measurement of intellect used the utterances that are commonly regarded as the images that held by individuals. The development of Arabic language was determined by a specific course that concerning in grammar and its derivatives. However, non native speakers of Arabic will face the difficulties, as in the practice of Arabic language learning that takes place in Islamic boarding schools. One of the studies about the wants of Arabic language mastery was put forward by Hanafi (2010: 30) about three issues that concerning in this learning problem. First, the extent of the practice is commonly using I'rab. In this case, the beginner will find difficulties. Even though, the mastery of Arabic is not solely measured by the ability to decipher the words to sentences by using the 
'I'rab'. Thus, it cannot be said that it is literally learning by using Arabic, but it is studied about Arabic itself.

Second, the discussion on the topic of nahwu is very detailed. With the consideration of efficiency and effectiveness, the material is supporting the language learning process, unless, it is used to obtain a deeper understanding of Arabic in certain studies such as in literature and language study program. But for students that are targeted to explore deeper religious knowledge, the first step is not the right choice for teaching language with all aspects of nahwu in detail, it turned to be inaccurate and overlap. The last, textbooks which are used is fully made in Middle Easters. It can be interpreted that the language in the book is specifically for the native speakers of Arabic, not as a second language. Hence, it will deny the existence of the sociolinguistic context of languages that differ between Middle Eastern cultures and Indonesian traditions. The relevance of the material in the books is a matter, it makes the distance between the discussion of the lesson and the reality in daily life.

As the response to these three problems, the education of pesantren introduces the modern terms to be an alternative to traditional learning. By using a communicative approach, it is used as an innovation to improve the existing process of Arabic language education. Meanwhile, the emergence of the tendency to make Islamic studies as a tool for practicing the understanding without specifically explore the viewpoint of the ulama (Islamic theologician) that contained in Kitab Kuning is a demand.

By accepting Islam as a religion, Arabic is subsequently absorbed as a language of religious. The absorption of Arabic into Indonesian extends in various contexts, includes social traditions. Some of the vocabulary was also absorbed in the political fields, whereas the political developments encompassed Islam with its spread (Abdelhay, Makoni, Makoni and Mugaddam 2011: 457). The closeness of the language makes the attraction to learn Arabic also adorns the aspect of diversity. The recitation of Al-Quran and Hadith and prayer are all using Arabic. This position made Arabic became the most important language to carry out Islamic shari'a (Islamic justice). It includes in making Arabic as the main language because it has become an option as a communication language that chosen by Allah. Communication of Allah with His servants by choosing meanings that implied in Arabic. The acquisition of fusha (modern standardization of Arabic) language is an important activity in Islamic boarding school education. Although in Arabic itself, the process of communication in local dialect languages became a major concern (Boudelaa and Marslen-Wilson2013: 1453).

The uniqueness and typical pesantren in Indonesia is a supporting force for the presence of Islamic education institutions. In this factor, Arabic developed because it became the main subject in the pesantren. The establishment of this Islamic boarding schools is intended as an institution to strengthen the religious understanding. Hence, the choice of language that is used as a medium of interaction by choosing Arabic is because of it is as the language of revelation. Islamic boarding schools with ideologies like this then become traditions and develop to follow the existing environment. As a religious institution, the presence of pesantren in the society becomes important. There is a process which society truly trusts as a center of educational primacy. Including outside religious affairs, the role of pesantren continues to grow. Like the socio-political role, during the campaign period and practical political affairs, pesantren can be used as a mainstay to gain votes.

\section{B. Traditional education vs Modern learning}


In the modernization of education, one of the phases initially carried out by Muhammadiyah community. The presence of Muhammadiyah intended to provide learning for the Islamic community with a faster process of transforming education. It is unlike where the learning process takes longer and has less learning material. The system that is commonly used by Europeans is adopted. Even, it includes about how to dress in the learning process is also modified and adopted to Western manner. Practical orientation became the basis for initiating the changes introduced. The references of the western education then became more prominent and later became a reflection to the implementation of education.

Particularly, the modern words that inherent in Islamic boarding school education are used by Pondok Moderen Darussalam, Gontor as known as the Gontor Islamic Boarding School. The name Gontor itself is the name of the village where the Pesantren Darussalam is located. This modern word is attached by the founders to describe the education system and the method used. There is a difference with the traditional education system known as salaf. At that time when Gontor was opened, Islamic education institutions had not used tables, chairs and blackboards yet. All of them were actually introduced from the beginning by Gontor. Including the use of classical and class systems in the daily learning process.

One of important aspect is also the use of Arabic and English as a tool for mastering sciences. 'Salaf' Islamic boarding school at that time had not used both of foreign languages as a learning material. It is only the study about the kitab (book). And that is done by listening to the lecture of the teacher or senior santri (senior students). The language that learned at Gontor is not only memorization or grammatical, but the language is practiced and used as a language of communication in the cottage environment. It is not only in classical Arabic, but also the modern Arabic.

It does not mean that Gontor completely abandoned the pattern of education that had developed for a long time in the tradition of pesantren. Something that took place in the previous pesantren was used as a basis for development then. It includes the presence of a integration of classical learning traditions that have been taking place in salaf Islamic boarding school, it also completed with a modern curriculum and style which adapted from the West. Thus, there is a comprehensive education system and also presents a modern scientific integrity. Likewise, it does not leave the treasures of established classical lore. The books and classical knowledge are taught in a modern way. Then, the time can be shortened, achievement and results of learning and comprehension are more adequate.

If it can be seen as Prophet taught his sahaba (close friends), they only formed halaqah (the circle). But, the increase of the number of Muslims after the Prophet passed and also the need for the process of transforming religious knowledge, then ma'had and riwaq existed. The forum of Ulama (Halaqah Ulama) who were initially only for the community in the mosque, could no longer accommodate the students who were present from various corners of the place, as a response to the development of Islamic education at that time. Educational facilities that only for the mosque interest, then it developed to be the place to study and live for students. In particular they also need a place to review the lessons that have been obtained in the mosque.

For this reason, the further development is ma'had (dormitory) which is already in a certain area while providing complete facilities and other educational facilities. The distance from their hometown to the mosque which is the center of education is the reason to build dormitories with its facilities. Then, the tradition of waqf grows along with the presence of these various needs. The development of waqf then shows that the mosque is more than only 
a place for praying, it is also a place to study religion for knowledge seekers present from different places. In developments like this, it is not handled individually any longer, but it requires a team presence even though it's still in the form of a small group. However, interpersonal coordination is needed to run this endeavour.

One important sign for Islamic education is the presence of the "Kitab Kuning". These Arabic books become a tool in education. Through this book, the excavation of classical Islamic khazanah is obtained. As a form of continuity of this book, it used the sorogan and bandongan system. In the sorogan system, the student listens to the reading of the book which is read by Kyai (clerics) individually. Hence, every Kyai teaches one book. A student who had finished reading the certain books to Kyai the in one pesantren moved to another place to learn a different book.

The bandongan system, as known as wetonan, is a group of student that listening to the lecture of Kitab (book) and spoken by Kyai. They give denotation or conclusion to the Kitab. The Kyai or his assistant who came from senior santri with a mandate of Kyai after being considered capable of teaching the book and gave a lecture to a group of student. In turn, the santri will listen to the readings and understand of the explanation that is previously described by the Kyai. In the sorogan and bandongan systems of the translation and qawaid methods, In the process of reading that is referenced by the kiyai, is only read and translated. Furthermore, the translation is given to the explanation of the rules that formed the sentence. The activities of the santri in giving syakal (lines), write down the meaning of the word, as read by the Kyai. In this learning process, the ability of the students that is obtained are translating and analyzing the sentences. Speaking ability is not obtained here because there was no practice at all.

The both forms are not limiting the existence of classical method. As Bawani (1990: 105) explained, that use of classical method is still carried out in traditional Islamic boarding schools. But the group-forming is based on its book, not the grade, level or classification in other categories. In traditional Islamic boarding schools, the reference that used is a book. The durability of traditional Islamic boarding schools remains an important meaning. Because it cannot be interpreted that the use of traditional method will then make the institution dispersed. Still, they can survive the conditions. The traditional meaning is more to establish a pattern that has been adopted before. Without being affected by patterns that are then introduced or adopted from other cultures. Tradition has the interpretation of what grows inside and maintained as a form of culture.

Arabic learning is formally carried out from Madrasah Ibtidaiyah (Islamic Elementary School) to college. At the upper education institutions, several universities teach Arabic with a certain allocation. It's just a concern, with the long experiences of study in decades, study of language is still being an obstacle. It means, there is a problem in Arabic learning. Observing the conditions in several institutions such in State Islamic University of Maulana Malik Ibrahim Malang, East Java, gave the obligation to students to stay for a year in a dormitory. This is an attempt to enrich the ability of the Arabic language during the stay. It absolutely can help the students to understand and comprehend the material in the next semester. The creation of this environment and conditions can support mastery of language.

\section{Islamic Boarding school in Muslim Minority Area}

The desire to obtain an educational process that is oriented towards Islam is the incentive for the growth of educational institutions, even in Muslim minority context. Along 
with regional expansion and government administration on the island of Papua from one province into two provinces then opened the opportunity for the Islamic community to participate in developing educational patterns. In order to fulfill the transformation of formal religious, the initiative to establish educational institutions was carried out in their respective communities. It does not need to be in a wide place, even mushallah is also used as a place to study for the surrounding environment. For children they learn to recite in the afternoon. While for the adult worshipers they study after the prayer.

The role of Islamic boarding school as institution is to forge the young generation in various skills by instilling an entrepreneurial spirit. It can introduce the students with a broader pattern of life. Response to the environment, creation of social order, internalization of morale, and acceptance of the dynamics of religious life become the programs to be developed in the curriculum. Likewise, the social life of Muslim societies becomes part of the teaching itself. The power of pesantren is mainly in supporting existence and also maintaining a fundamental role. This cultural identity is an institution to always protect the moral values.

If the establishment of an Islamic boarding school is because of a charismatic figure and knowledgeable towards the religion, there is a management and group strength that made the existence of a pesantren in a Muslim minority area. Kyai or ulama who were not existed in the institution's environment are subsequently replaced by the implementation of education based on modern management. The management power which is the unity is carried out in an organizational form. It is not relied on religious knowledge, honor, and authority. With this system, there is a power that is formed to run the existing potential. Along with that, a system is built to become a guide in running an organization in the form of a foundation. Distribution of authority is one of the keys to success, and the functions run as the increasing of needs and ongoing activities.

Papua, including West Papua, accepted Islam since 1852 which began at Misool (Muller 2008: 88) with the activists of Seram and Bugis traders. With the encountered of traders from Tidore and Ternate, it made the West Papua coastline obtained the information about Islam. Even Wanggai (2009: 232) explained that the acceptance of Islam actually began since the 15th century. Both of these data, although distinctive, both provided information that the spread of Islam in Papua has taken place in a matter of centuries. From the acceptance of Islam through the merchants, the educational institutions also grew which became the process of transmitting religious knowledge. The population who converted to Islam became a necessity to place Islamic education teachers in government and private schools. Even though the school is managed by a Christian institution, Islamic education teachers were provided. Practices like this can be found in Namatota, Kaimana, where a Christian school grew in the environment of Muslim communities, they also provided teachers for Muslim students.

Islamic education is not realized to only build individual piety. But there is a collective awareness that will be built through the community. This orientation is a target to build this awareness to form individual Muslim piety through educational institutions. From the outset, institutional development has been pursued in the formation of cultures before forming the structure. Academic reinforcement that was addressed became the main agenda to build the main foundation. An Identity became an important issue to be the basis of the development of Islamic education. It needs an institution that can provide religious understanding from the perspective of its followers. It is also a matter if the religion 
teacher who teaches Islamic education is not a Muslim, or there is no Islamic teacher available because the facilities provided by the Education Office are inadequate where students are not more than ten. Therefore, the daily interaction with followers of other religions did not enable an opportunity to strengthen a Muslim identity. The choice is precisely to put the children to pursue scientific activities in institutions that specifically run by Muslims.

One of the most important factors to understand A-Quran authoritatively is to use the Arabic approach. Hence, one of these goals learning Arabic as the main language is used as a goal. The inability of Arabic mastery will also lead to incomprehension of Al-Quran itself. That is such a necessity for the students to be mastered in using this language. So, it will help them in understanding more about Islam. Therefore, the characteristics of the language are not the same as mother tongue. Among the dynamic language characters, the richness of vocabulary and its formation, structure, rules, and usage that rely on change of reading materials. It becomes a basis for the effort to the direct language learning that can be carried out simultaneously. Then, it eliminates the impression that learning Arabic is an obstacle.

By looking at the existence of established pesantren on other islands, the establishment of a pesantren in West Papua took the position from the start, the model of the pesantren that was used as a reference. This is solely to facilitate management of aspects that will be used as learning primacy. Each pesantren has its own peculiarities; Gontor with its foreign language learning, Bangil with fiqh, Tebu Ireng with its Kitab Kuning, etc. So the standard that used for the management of a pesantren has become a necessity. While in other cases, there is also pesantren which originated from orphanages. So that it becomes a typical practice if there is a merger between pesantren and orphanages.

There is a choice by making Gontor as a plural choice because of the institutional structure that integrates Islamic boarding schools with formal schools. For formal education, the choice of one of them is education with the structure of the Ministry of Education and Culture or the Ministry of Religion. This is also to support the students with formal diplomas by government institutions. The institutional format with formal schools is easier to be integrated with the boarding school system. The next development also carried out Madrasah Diniyah, as a religious education system that was run with the integration of the school system.

\section{Initiative in Arabic Learning}

Since the beginning of the language education program, especially in Arabic, it was intended as one of the leading programs in Islamic boarding schools. Observations and interviews that conducted during the research process indicate that the process of establishing Islamic boarding schools has shown to provide comprehending of language skills. The curriculum was developed by including the largest portion of the supporters of the learning process in mastering foreign languages namely Arabic and English. In particular, this study will only describe Arabic learning. The adaptation from Islamic boarding schools such as Gontor, Assalam, and Darunnajah, was carried out to fulfill the need of a curriculum to become a learning guide. The collaboration like this is a consideration that not only one institution is used as a reference. But with all the 
advantages, it can be used simultaneously. Thus, a program from various institutions will be created and be integrated.

As well as the completeness of educational administration, the modification of curriculum which is adapted to the input skill of students from elementary schools is done to lay the fundamental for the next educational process. The first set of actions is the determination of the curriculum that will be used in providing learning experiences to students. This is adjusted to the needs analysis and also the analysis of the environmental conditions in the surrounding of the institution.

This conceptualization was then continued to become a document that became a guide in carrying out the mission of education. The current condition anticipation and the challenges of the future are two main concerns. With this document, the answer of the future to the present are all contained in the curriculum documents.

The curriculum consists of two levels, Middle School (SMP) and High school (MA). Two levels with a different choice of affiliation, but in the educational process in the boarding school are put together in the form of a dormitory. Thus, the programs that is related to Arabic language skills is not a part of the SMP and MA curriculum. The formal education curriculum has been established by the ministry from the beginning. But, the curriculum that used by Islamic Boarding School (pesantren) as non-formal education it is entirely the authority of the its management. After school time is used to study an additional lesson by every students in its curriculum of Madrasah Diniyah. Every year, an evaluation and improvement are carried out in the curriculum, so, the determination of the students' abilities will be achieved and improved.

The communicative approach is an option in running the curriculum. The ability that will be developed with the determination of the curriculum is an active language skills, namely speaking and listening. For grammar ability, it is the theoretical passive ability with the function to produce sentences in accordance with the grammar guide. But it is not intended to explain in detail the of linguistic rules. Otherwise, the rule can be used to make sentences as rules and use sentences in the form of communication in real terms. Students are also required to interpret various contexts of the sentence according to the language used. This interpretation is carried out routinely through communication practices, not in a manipulative form but actually takes place in daily life. The existence of an Islamic boarding school environment becomes important as a learning laboratory.

The presence of teachers in boarding schools is an encouragement to oversee the communication process. Each student is gradually directed to reduce the use of their first language. Likewise in learning, the language of instruction does not use mother tongue but Arabic itself. The two things of this learning approach are the detailed learning syllabus and sustainable application to support the communication process. Not only in the classroom, the environment and all activities that run in the pesantren environment support the continuity of the entire process in actual forms of communication. The use of language that is achieved through practice is the actual interaction, practice, improvement, and also evaluation as a learning tool. The interaction in the environment is the learning activity of the students for mastering language as a tool in expressing ideas.

The method that used in the implementation of the curriculum and learning material is al-tariqah al-mubasyarah (direct method). In line with the approach used, this method can be used to achieve the stated learning goals. The main principle in applying the approach to the method is acceptance. In this principle, mutual understanding and understanding of the 
communication process will be an interaction. The ability to interpret an utterance in context will be the mastery of language includes the relevance of use to the social norms that is adopted.

Even a simple learning media such as blackboard are used. All learning processes use these tools. So, the blackboard is placed in class, mosque, public place, and hall. Vocabulary is written on the board periodically replaced. Then the students were directed to write vocabulary while memorizing it. The memorization of the students' vocabulary starts from the surrounding environment. All objects in the boarding school environment become learning tools. It is then used in daily interactions.

The patterns used in this method include the use of Arabic as a tool for communication during the teaching-learning process, likewise with the translation of existing vocabulary. Otherwise, it is only by showing pictures or movements so the students can interpret a meaning from the vocabulary. At this time, the students had to memorize vocabulary. Day by day, vocabulary is mastered by the students. Furthermore, the vocabulary is explained by its use in a sentence. Placement of different sentences then spreads to the students the position of a vocabulary in the sentence. Again, there is no need to translate these sentences. During the training, the students were asked to form sentences according to the existing patterns.

The implementation of the education cycle with this pattern also requires a basic book. By using a book written by Imam Zarkasyi, learning using Gontor's principles will be more in line. The book entitled "Durus al-Lughah al-Arabiyah" became a handbook for the students. The book is entirely an experience in applying the language learning process at Gontor. None of them used translations in Indonesian. Books are written by introducing vocabulary. After that, each chapter has a specific text that becomes exercise. The vocabulary that is introduced at the beginning of the chapter is used in the pattern of sentences formed. Thus, even though there is no Indonesian language, the book can be used as well as become a guide for students in learning. The communicative function becomes a plot in the preparation of the book and there are no specific grammar rules with technical explanations. The unit is a combination of using many sources of how interactions in the environment are gathered from daily conversations.

In the exercises, there were techniques that were implemented to become an exercise for the students in mastering vocabulary. First of all, the sentence is pronounced according to the example given by Kyai (cleric). Then the students repeat the sentence that is said. After that, the sentence is used in various sentences according to the pattern. At the end, the students write down the words. Writing is not the beginning of the process. When the students had memorized and used the word in the sentence, After that, they write it down to keep the memory or for the sake of repeating the lesson.

When the guests (the native speaker) come, the students can interact with the guests. The guests were asked for their willingness to motivate them in a foreign language. This is one of the media for the students to communicate with foreign language speakers. The activity like this is expected for improving the interest of students in learning foreign language. They also cultivate the pride and self-confidence in communicating their ideas in public. Some guests came for other duties, such as Qatar and Saudi Arabia.

The lesson about principles is also given. But, this is specifically for advanced levels. When there is a lesson of essay writing process, the principles that are presented but in not detail. But, it is how the students use this principle in the writing process. So, the 
composition of teaching for qawaid material is not dominating. Students learn to write for improving insha 'skills (composing sentences). Periodically, they will write the essays with selected themes. By writing those sentences, the mistakes that are made in the previous writing can be used as learning material for the next writing activity.

One of the way to maintain is by forming the Al-mahkamah Al-lughawiyah. There is a rule, that they are forbidden to speak in Indonesian languages or dialects, so, the practice must be in accordance with the specified day. Even if this regulation is stipulated but not monitored, it will be in vain. For this reason, students who broke the regulation previously were asked to write the their name, They become jasus (spies) to monitor the students. Furthermore, the name of those students are summoned and announced. Then, additional lessons are given because of using Indonesian or dialects. They also were given additional assignments to memorize vocabulary and also clean the campus environment.

The integration of various components of education is run simultaneously into an integrative learning. There are four things that are of major concern, namely the class target which is focused on communication skills. Second, the techniques aim to provide the authentic learning. All activities are actually in the real conditions. Third, students' involvement is needed by prioritizing fluency and accuracy. Furthermore, they will be examined, not by memorizing the principles. The last, language is used spontaneously and productively.

\section{Result and Discussion}

This research showed that the learning structure was established to achieve language skills in language acquisition as a tool. The use of methods, media, and teaching materials is adjusted to the objectives set. According to Barton (1999: 75-77), Islamic education institutions in Indonesia that is carrying out the modern term are actually a liberal integration. It is a classical learning tradition that is integrated with modern Western style and formed in the teaching and subject systems. As Purohit (2011: 709) stated that in the identity that was built up in Asia, there are conviction and learning practices that could accept ideas from west world, especially Europe and America. Thus, Indonesian Islamic education actually makes this integration as an attempt to organize educational institutions by adopting its advantages from other parts of the continent, even though it is not a Muslim country.

The most important element in the formation of curriculum and learning material is the religious and cultural value that is adopted. It is not just concering to to fiqh but it is also necessary to make Arabic learning as a framework that underlies the development of education. With the concept of moderation in language learning, it is actually just an innovation in practice that has been undergone. The main goal is finding out the form of the curriculum that will guide the implementation of the education process. When this curriculum has accommodated the institutional interests, the teacher can easily implement it in teaching and learning activities. As Kazanjian (2012: 187) in curriculum research that are responsive, it always takes an initial effort to absorb the aspirations of the surrounding environment, that curriculum is not only as an academic matter, but as a means to build the future.

Meanwhile, an educational process can be used as a new tradition. Religion is a medium of communication in bridging between tradition and modernity (Pace 2011: 205). In the study, Pace suggested that social dynamics would experience a transformation. The existence of a belief system called religion will be enlightened in interpreting the social conditions that occur. So, social religion will help in finding a meaning in the development that 
occurs. Likewise in the Buddhist religious tradition that took place in Thailand (Johnson 2013: 71), religion accompanied the social processes, so, they can be proponent in running the common interest.

The learning environment is the most important part of this process. Environmental support for an educational practice becomes a stimulus for development. Such as the use of Arabic in Islamic boarding schools in daily communication. The principle that is used in implementing such of practice is not because of the ability of the santri but it is an effort in the formation of the environment. These conditions are the obligation for every santri to participate in this rule. When it is formed, the santri automatically can use Arabic as a means of communication in life in the boarding school environment. There is a change in communication patterns that carried out by students. As in the research of Mall and Nieman (2002: 42) also found out in Africa and Bostwana, They considered that the pattern of translation and grammar would be the basis for studying about religion. In fact, using a pattern like this requires a long time. At the same time there is no guarantee of mastery of the material because learning emphasizes more on linguistic aspects, not the use of language that is learned.

Learning languages can gain and establish insight. The mastery of numerous languages will form the different dictions. Furthermore, language will become an identity. In speech action theory (Austin 1962) it will be temporal and individual. Language styles, viewpoints, and dialects are commonly found in everyone who learns language. The importance of linguistic communication becomes a stimulant of aspects that can be achieved from a speech. This will lead to both production and understanding of speech. The main goal is to understand the purpose of communication, as it is already developed of the understanding of actions in linguistic forms. There are interpersonal and interactive functions that can be used, not in the form of a theory but at the implementation stage.

This research showed that the same perceptive between all elements in education is needed to achieve the stated goals. To make this achievement realized, management is important. Without it, Education is equal with nothing. A synergy will be a major force in the management of education. Although Islamic boarding school is the institution that focus on religious studies, management issues is still a major concern. Even in running a religious organization, management must be carried out with a certain design. Without it, the goal that is achieved will be far from expectation (Tamkin 2012: 90). As in the research in Sorong (Wekke, 2011), with the governance that is considered, the role of pesantren can be a pioneer in society activities. As a force, Islamic boarding school is able to manage the education process while providing skills to the students. Thus, the practice that carried out in the context of learning becomes an experience as an opportunity to interpret these activities.

This research showed that the integration of culture into the elements of education management that will help the formation of a system. With the implementation of this system, it will be easier to form a program in a series of achieving organizational goals together. It includes the use of technology to be a media, so, the learning outcomes can be maximized. At the same time it becomes a tool in enriching students' learning experiences (Wekke and Hamid 2013). In a broader cultural context, the condition of minorities will be a support of the need for socialization with the existing environment. Like American Muslims, they use its identity constancy as a behavior. At the same time, they continue to make American patriotism as a tradition of American nationality (Rastegar 2008: 455). 


\section{Conclusion}

The study of language education in this paper was carried out to reveal a discussion of modern principles that are used. The program was specifically made with regard to curriculum, approaches, methods, techniques, media, teaching materials and materials. Modern pattern implementation that is concerned to the communicative approach is the main goal of the language education process. It is subsequently followed by the use of the direct method (al-thariqah al-mubasyarah). The synergy between approach and method becomes an intergration of accomplishing the effort to achieve the learning objectives that have been determined. The key of this success is consistency, seriousness, innovation, and integration which become the support, so, the education insights set are achieved. To achieve the communicative competence, there are many things that are related to one another, not just concern in one thing.

Grammatical mastery is still important, but this is not the main material. Thus, in the learning process, it is not taught in the form of qawaid in the form of nahwu and sharaf. The grammar is commonly used in the form of expressions that have been formed in uslub. The vocabulary is used as in the example of the sentence pattern. The existence of material book is specifically designed to be a guide in learning. The book that is made in the Middle East or a heritage book from the previous century is not used. The use of language rules in that book is more prominent than language applications. All of those are necessary to improve the language skill, not comprehending the material that is related to Arabic language.

Furthermore, the educational environment becomes a pillar for the contextual practice in daily life. In the environment, the practice of communication is applied in accordance with the learning pattern. The opportunities to interact, Using the abilities that have been obtained in the lesson, Understanding the context of a sentence, and interpreting the utterances are being a completeness in learning. Learning languages is not just in the building, but the educational environment is also a means for sustainable learning process. This environmental support becomes a means as well as a laboratory. The pattern of communication can be carried out in the real environment, Languages are spoken and maintaining the vocabulary that has been learned. Finally, the equality between desire, management, and implementation with an integrated pattern improves the mastery of language that can be used as a communication tool.

\section{References}

Abdelhay, Ashraf; Makoni, Busi; Makoni, Sinfree; dan Mugaddam, Abdel Rahim. 2011. The sociolinguistics of nationalism in the Sudan: the politicisation of Arabic and the Arabicisation of politics. Current Issues in Language Planning. Vol. 12, No. 4:457-501.

Austin, John. 1962. How to do things with word. Cambridge, MA: Harvard University Press.

Barto, Greg. 1999. Gagasan Islam liberal di Indonesia. Terj. Nanang Tahqiq. Jakarta: Paramadina.

Basyir, Zainul Fuad. 1999. KH Imam Zarkasyi tentang modernisasi pondok pesantren: studi kasus di pondok modern Gontor. Tesis Program Pasca Sarjana Universitas Muhammadiyah Malang: Malang.

Bawani, Imam. 1990. Tradisionalisme dalam pendidikan Islam. Surabaya: Al Ikhlas.

Boudelaa, Sami dan Marslen-Wilson, William D. 2013. Morphological structure in the Arabic mental lexicon: Parallels between standard and dialectal Arabic. Language and Cognitive Processes. Vol. 28, No. 10:1453-1473. 
Dhofier, Zamakhsyari. 1982. Tradisi pesantren: studi tentang pandangan hidup santri. Jakarta: LP3ES.

Gellel, Adrian. 2007. Valuing the language of intergenerational wisdom in the spiritual education of children. International Journal of Children's Spirituality.Vol. 12, No. 1:1-3.

Johnson, Andrew Alan. 2013. Monks and Magic: Revisiting a classic study of religious ceremonies in Thailand. Asian Journal of Social Science. Vol. 41, No. 1:69-71.

Kazanjian, Christopher. 2012. Finding a worldly curriculum:utilizing a cosmopolitancurriculum in a global community. Journal of Global Responsibility. Vol. 3, No. 2:187-197

Mall, M. A. dan Nieman, M. M. 2002. Problems experienced with the teaching of arabic to learners in muslim private schools in South Africa and Botswana. Per Linguam. Vol. 18, No. 2: 42-54.

Moos, R. H. 1979. Evaluating educational environments. San Fransisco: Josey-Bass Publishers. Muller, Kal. 2008. Mengenal Papua. Jakarta: Daisy World Books.

Mylek, I dan Nel, P. 2010. Religion and relief: the role of religion in mobilizing civilsociety against global poverty. Kotuitui: New Zealand Journal of Social Sciences Online.Vol. 5, No. 2:81-97.

Pace, Enzo. 2011. Religion as communication. International Review of Sociology: Revue Internationale de Sociologie. Vol. 21, No. 1:205-229.

Permani, Risti. 2011. The presence of religious organisations, religious attendance and earnings: Evidence from Indonesia. The Journal of Socio-Economics. Vol. 40: 247-258.

Purohit, T. 2011. Modern Asian Studies. Identity politics revisited: Secular and Dissonant Islam in Colonial South Asia. Vol. 45, No. 3, (May):709-733.

Rastegar, Mitra. 2008. Managing 'American Islam'. InternationalFeminist Journal of Politics, Vol. 10, No. 4:455-474.

Tamkin, Penny. 2012. Leadership by design. Strategic HR Review. Vol. 11,No. 2: 90-95.

Wanggai, Toni Victor M. 2009. Rekonstruksi Sejarah Umat Islam di Tanah Papua. Jakarta: Badan Litbang dan Diklat Departemen Agama.

Wekke, Ismail Suardi dan Hamid, Sanusi. 2013. Technology on Language Teaching and Learning: A Research on Indonesian Pesantren. Procedia - Social and Behavioral Sciences. Vol. 83:585-589.

Wekke, Ismail Suardi. 2011. Pendidikan Islam dan pemberdayaan masyarakat (tinjauan pendidikan vokasional pesantren Rodhotul Khuffadz Sorong. Jurnal Kajian Islam Hermenia. Vol. 10, No. 1 (Desember):23-53.

Wekke, Ismail Suardi. 2012. Amalan pengajaran dan pembelajaran Bahasa Arab di Pesantren Immim Makassar, Indonesia. Tesis Ph.D. Fakulti Pendidikan Universiti Kebangsaan Malaysia: Bangi.

Woodhead, Linda. 2011. Five concepts of religion. International Review ofSociology: Revue Internationale de Sociologie. Vol. 21, No. 1:121-143. 